\begin{tabular}{|c|c|}
\hline \multirow{3}{*}{ 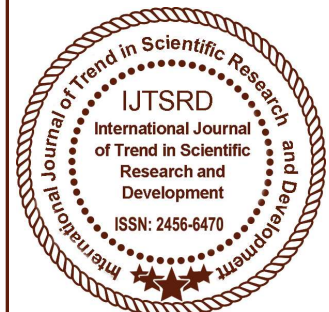 } & $\begin{array}{l}\text { International Journal of Trend in Scientific } \\
\text { Research and Development (IJTSRD) }\end{array}$ \\
\hline & International Open Access Journal \\
\hline & ISSN No: 2456 - 6470 | www.ijtsrd.com | Volume - 1 | Issue - 6 \\
\hline
\end{tabular}

\title{
Spatio-Temopral Rain Fall Variation ; A Case Study of Western Part of Hunsur Taluk, Mysore District, Karnataka, India
}

\author{
Gangadhara G \\ Research scholar, Department of Studies in Geography, \\ Manasagangotri, University of Mysore
}

\begin{abstract}
The present study has been conducted to assess the spatial variations in rainfall in Hunsur taluk, Karnataka, India. In order to discuss spatial and temporal variations in rainfall, 5 rain gauge stations have been chosen to collect data for the years 1985 to 2005. Data have been collected mainly from the District Statistical Office, Mysore. These collected data have been used to examine year-wise spatial variations of rainfall using ArcGIS. Co-efficient of variation has also been computed to assess the area where average rainfall can be expected, in the future. The result shows that, the study area has fluctuations in rainfall and Hyrige raingage station received maximum annual rain, Hunsur tobacco research center received minimum annual rain and Undavadi received lowest annual rain fall.
\end{abstract}

\section{INTRODUCTION}

Hydrometeorology is a branch of meteorology and hydrology that studies the transfer of water and energy between the land surface and the lower atmosphere.rainfall is an important element of economic growth of an area or region, The study of rainfall distribution pattern and its temporal variations is very important, as the country's economy and

agriculture it helps to explaining the various socioeconomic problems The amount of rainfall does not show an equal distribution, either in space or in time. It varies from heavy rain to scanty in different parts. It also has great regional and temporal variations in distribution. Therefore, the study has been conducted in order to help farmers to for cultivation process

\section{STUDY AREA: HUNSUR TALUK, KARNATAKA INDIA.}

Western part of Hunsur The taluk is bound on the north by Mysore and part of $\mathrm{k}$ r nagar taluk and on the east by H D kote. piriyapattana forms its western boundary and the southern portion is covered by kodagu district. lies between latitudes $12^{\circ} 15^{\prime}$ to $12^{\circ}$ $25^{\prime} \mathrm{N}$ and longitudes $76^{\circ} 5^{\prime}$ to $76^{\circ} 25^{\prime} \mathrm{E}$ SOI no $57 \mathrm{D} / 3,57 \mathrm{D} / 4,57 \mathrm{D} / 7$ and $57 \mathrm{D} / 8$ covering an area $633.77 \mathrm{Km} 2$., headquarter of Hunsur taluk, is located about $35 \mathrm{~km} \mathrm{NW}$ of Mysore city. Most of the places in the study area are well associated by roads. National Highway No. 88, passing through the western and eastern part of the study area, The climate of the hunsure is moderate throughout the year, and the district gets rainfall during two seasons, namely, the southwest monsoon season or rainy season, which is between June to September and retreating monsoon season during October and November. 


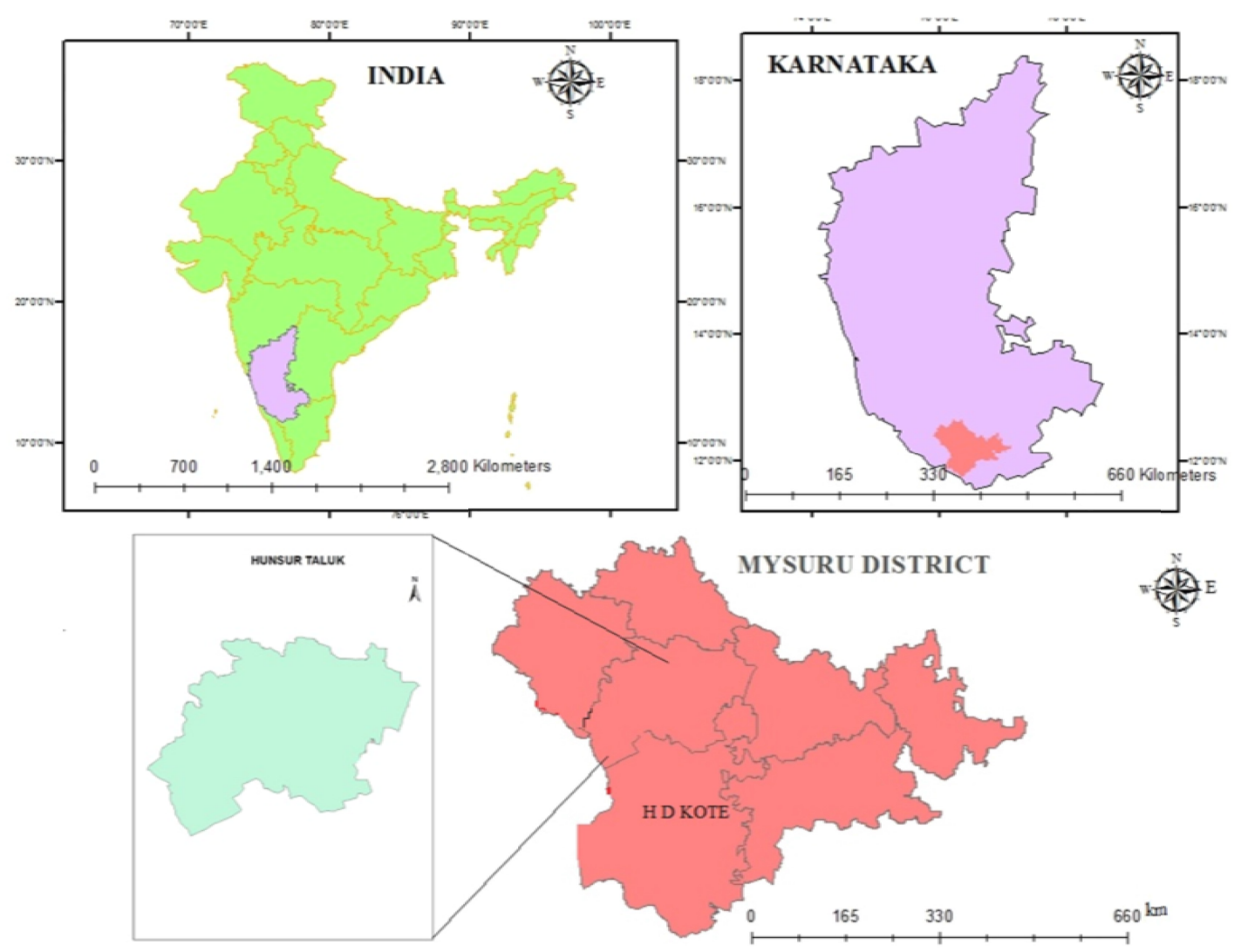

\section{RESEARCH METHODOLOGY}

The present study were collected from Tobacco research centre, Hunsur, Central Groundwater Board; Mysore and the Indian Statistical Department, Mysore.in ArcGIS. The co-efficient of variation method which used to measure the variation in the values, so this study also used co-efficient of variation to find out the temporal variation in the rainfall and the result of the analysis has been mapped to find out the spatial variations of co-efficient values.

\section{RESULT AND DISCUSSION: SPATIAL VARIATIONS IN RAIN FALL}

There are five rain gauge stations located in different places in western part of Hunsur, and these stations measure the precipitation throughout the year, Spatial
Variations: The analysis of year-wise spatial variations in rainfall shows that the study area has annual as well as seasonal fluctuations in rainfall, every year, The temporal classification of year wise rainfall distribution shows that during the year of 1988.1998.1999 2005 huge area have been covered by high and very high rainfall, while The average rainfall of the study area for the period 1985-2005 is $930 \mathrm{~mm}$. Annual rainfall in the study area during 2002 was very low and fell under severe drought condition. South-West monsoon and North-East monsoon, contribute $90 \%$ of the annual rainfall. The results indicated that south-western part of the study area receives higher precipitation compare to the north-eastern part which is mainly due to its hilly and forest area. 


\section{SEASONAL AND ANNUAL RAINFALL (MM) OF THE STUDY AREA (YEARS 1985-2005)}

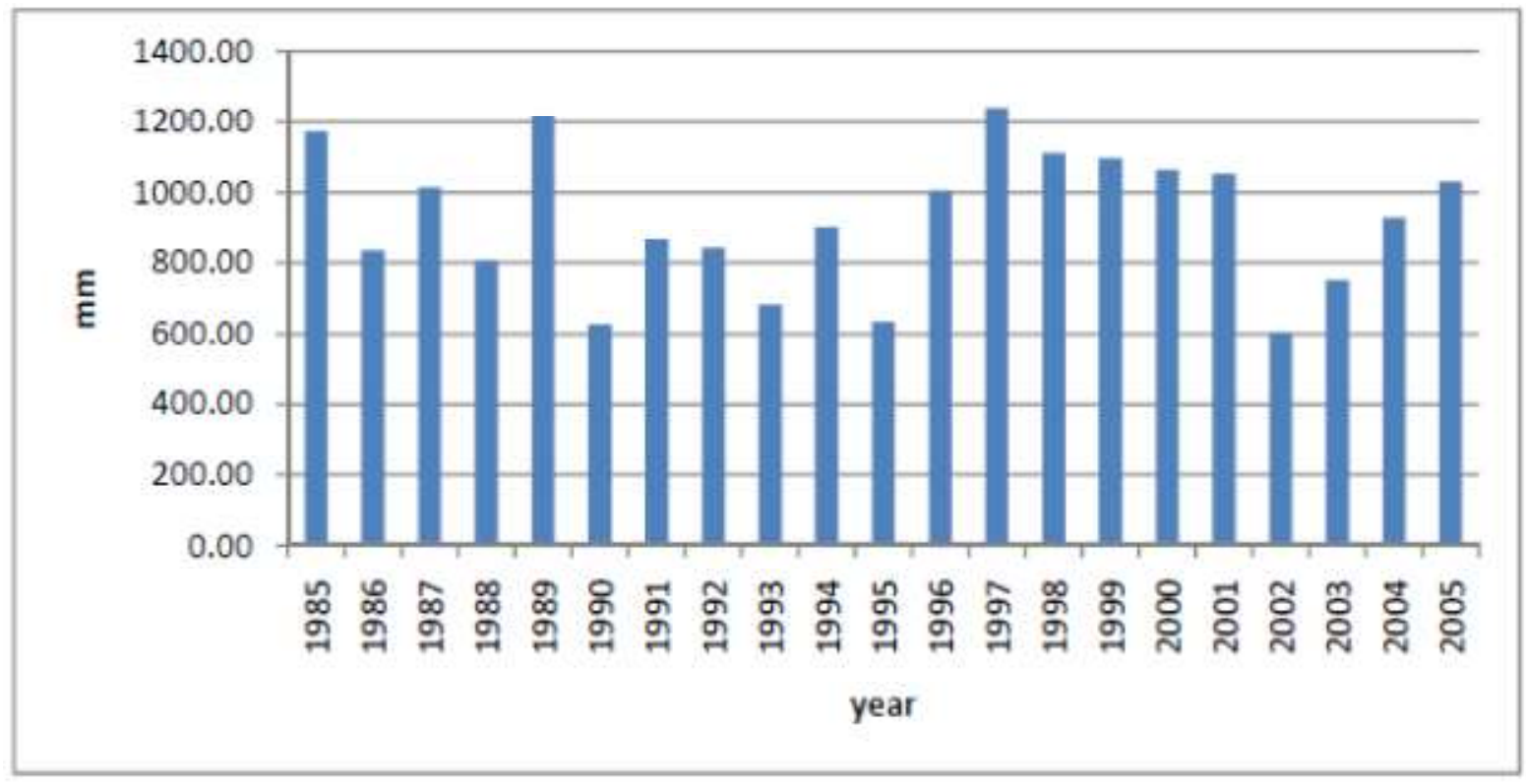

\section{CONCLUTION}

The spatial variations of year-wise rainfall show that the study area has fluctuations in rainfall both in space and time in all areas of the rain gauge stations. The maximum rainfall is received $(955.22 \mathrm{~mm})$ in Hyrige gauge station. where as the minimum of $922.54 \mathrm{~mm}$ is received in Undavadi station. In the study the annual average rainfall varies from 909.55 to $955.22 \mathrm{~mm}$ .The spatial distribution of annual rainfall by IDW method. The result of this study can help the people, those who depend on rainfall, especially the farmers to take necessary steps in their cultivation of crops in the coming years.

\section{REFERENCE}

[1] Edmore, Kori (2012): The influence of rainfall variability on Arable land use at local level: realities from Nzhelele Valley, South Africa, International Conference on Future Environment and Energy, IPCBEE vol.28, IACSIT Press, Singapoore, pp:218 - 223

[2] Jegankumar, Nagarathinam and Kannadasan (2012): Spatial distribution of rainfall in Salem and Namakkal districts, INTERNATIONAL JOURNAL OF GEOMATICS AND GEOSCIENCES, Volume 2, No 4, 2012 pp: $976-994$
[3] NeerajBhargava, RituBhargava, Prakash Singh Tanwar, Ankit Sharma (2013): Rainfall Spatial Analysis using GIS, International Journal of Advanced Research in Computer and Communication Engineering Vol. 2, Issue 5, May 2013, pp: $2197-2200$

[4] Khan,Asim (2000): A Spatio - Temporal Analysis of rainfall in the canal command areas of the Indus plains, International Water management Institute, Report No: R-104 pp: $1-35$

[5] Kusre, B. C. (2012): Study of spatial and temporal distribution of rainfall in Nagaland (India), INTERNATIONAL JOURNAL OF GEOMATICS AND GEOSCIENCES,Volume 2, No 3, 2012, pp: $712-722$

[6] Margaret R (1996) spatial modeling and interpolation of monthly temperature using kriging, CLIMATE RESEARCH, Vol. 6, pp: 215- 225

[7] Mohapatra, Mohanty (2006): Spatio-temporal variability of summer monsoon rainfall over Orissa in relation to low pressure systems, J. Earth Syst. Sci. 115, No. 2, pp. 203-218.

[8] Odekunle, Orinmoogunje, Ayanlade (2007): Application of GIS to assess rainfall variability impacts on crop yield in Guinean 
International Journal of Trend in Scientific Research and Development (IJTSRD) ISSN: 2456-6470

Savanna part of Nigeria, African Journal of Biotechnology Vol. 6 (18), pp: 2100-2113.

[9] Rathod, Aruchamy (2010): Spatial Analysis of Rainfall Variation in Coimbatore District Tamilnadu using GIS, INTERNATIONAL JOURNAL OF GEOMATICS AND GEOSCIENCES Volume 1, No 2, pp: 106 118.

[10] Jayawardene, Sonnadara, Jayewardene (2005): Trends of Rainfall in Sri Lanka over the Last Century, Sri Lankan Journal of Physics, Vol. 6, pp: 7-17

[11] Xuesong Zhang, Raghavan Srinivasan (2010): GIS-based spatial precipitation estimation using next generation radar and raingauge data, Environmental Modelling \& Software xxx, pp: 1-8.

[12] Latha, Rajendran, and Vasudevan (2014): Spatial analysis of rainfall using GIS in Veeranam catchment, Cuddalore district, Tamil Nadu, India, International Journal of Recent Scientific Research, Vol. 5, Issue, 1, pp:36-39.

[13] Vekateswaran, Vijay Prabhu, Suresh and Palanisamy (2012): Assessment of rainfall variability in GIS environment at Sarabanga subbasin Cauvery river South India, International Journal of Geology, Earth and Environmental Sciences, Vol. 2, pp:18-24

[14] Boye, Yakubu and Pokperlaar (2011): SpatioTemporal Variability of Rainfall Distribution in the Western Region of Ghana, Research Journal of Environmental and Earth Sciences 3(4), pp: 393- 399
[15] Tirkey Anamika Shalini, Pandey and Nathawat (2012): Groundwater Level and Rainfall Variability Trend Analysis using GIS in parts of Jharkhand state (India) for Sustainable Management of Water Resources, International Research Journal of Environment Sciences, Vol. 1(4), pp: 24-31

[16] Hazbavi and Sadeghi (2013): Analysis of Spatial Trend of Rainfall Erosivity in Iran, $1^{\text {st }}$ International Conference on Environmental Crisis and Its Solutions, pp: $434-440$.

[17] Sadeghi, Moatamednia, and Behzadfar (2011): Spatial and Temporal Variations in the Rainfall Erosivity Factor in Iran, J. Agr. Sci. Tech. Vol. 13, pp: 451-464

[18] Zengxin Zhang, Chong-Yu Xu, Majduline ElHaj El-Tahir, Jianrong Cao, V. P. Singh (2011): Spatial and temporal variation of precipitation in Sudan and their possible causes during 1948- 2005, Stoch Environ Res Risk Assess, Vol. 26,pp:429-441

[19] Yair Goldreich (1995): Temporal variations of rainfall in Israel, CLIMATE RESEARCH, Vol. 5, pp: 167-179

[20] Waleed, Rijabo, Hanee, Salih (2013): Spatial and Temporal Variation of Rainfall in IRAQ, IOSR Journal of Applied Physics, Vol 5, Issue 4, pp: 01- 07

[21] Tetsuzo YASUNARI, TelD.poral and Spatial Variations of Monthly Rainfall in Java, Indonesia, Southeast Asian Studies, Vol. 19, No.2,

pp:

$170-$ 